orthogonally with the electrodes in both Wenner and Schlumberger configuration, the rest only with Schlumberger configuration.

In so far as the results have been interpreted to date, the geoelectrical sounding method appears to be able to give relevant qualitative information in preliminary engineering geological investigation. Detailed quantitative information about the actual stratification can apparently only be obtained with a supplementary geophysical method, e.g. seismic refraction.

\title{
RECONNAISSANCE K/AR DATING OF SAMPLES FROM WEST GREENLAND BETWEEN SØNDRE STRØMFJORD AND FREDERIKSHÅB ISBLINK
}

\section{Ole Larsen}

interpretations in collaboration with

Brian F. Windley and V. R. McGregor.

$$
2860 \pm 20 \text { m.y. biotite }
$$

GGU 92133. Epidote gneiss (Finnefjeld gneiss), north of Ilivilik point, east of Napassoq. $65^{\circ} 04^{\prime} \mathrm{N}, 52^{\circ} 15^{\prime} \mathrm{W}$.

This sample represents the typical Finnefjæld gneiss. It is a medium-grained quartz-plagioclase-epidote gneiss with biotite and green hornblende. Microline has been identified as a minor component. Both feldspars are heavily twinned and quartz grains show polygonisation. Biotite, hornblende and epidote are intimately intergrown indicating that the rock has not reached full equilibrium after deformation. Sphene, apatite and opaque ore are all common accessories.

\section{$3117 \pm 40$ m.y. biotite}

GGU 92126. Amphibolite, Qerrulik, east of Napassoq. $65^{\circ} 02^{\prime} \mathrm{N}, 52^{\circ} 20^{\prime} \mathrm{W}$.

The sample is taken from a $1 \mathrm{~m}$ wide discordant amphibolite dyke cutting retrogressed gneisses which contain major relics of granulite facies gneiss. The area represents a transition zone between the retrogressed gneisses of the Fiskefjord region and hornblende-biotite bearing quartz-dioritic gneisses of the Finnefjæld complex.

The rock is fine-grained and consists of twinned plagioclase, unstrained quartz, green hornblende, brown biotite and a little epidote. Accessories are sphene, apatite and opaque ore. 
Table 2. Potassium - argon dates from West Greenland.

\begin{tabular}{|c|c|c|c|c|c|c|c|}
\hline Sample No. & Rock type & Locality & Geogr. position & Min. & $\mathrm{K}_{2} \mathrm{O} \%$ & ${ }^{40} \mathrm{Ar}_{\mathrm{R}} /{ }^{40} \mathrm{~K}$ & Age m.y. \\
\hline GGU 92133 & $\begin{array}{l}\text { Epidote gneiss } \\
\text { (Finnefjæld gneiss) }\end{array}$ & $\begin{array}{l}\text { North of Ilivilik point, } \\
\text { east of Napassoq }\end{array}$ & $65^{\circ} 04^{\prime} \mathrm{N}, 52^{\circ} 15^{\prime} \mathrm{W}$ & $\mathrm{Bi}$ & 9.02 & 0.3918 & $2860 \pm 20$ \\
\hline GGU 92126 & Amphibolite & Qerrulik, east of Napassoq & $65^{\circ} 02^{\prime} \mathrm{N}, 52^{\circ} 20^{\prime} \mathrm{W}$ & $\mathrm{Bi}$. & 7.6 & 0.4660 & $3117 \pm 40$ \\
\hline GGU 89900 & Hypersthene amphibolite & West side of Ankerbugt, Tovqussaq & $64^{\circ} 53^{\prime} \mathrm{N}, 52^{\circ} 12^{\prime} \mathrm{W}$ & Hbl. & 0.50 & 0.3636 & $2750 \pm 60$ \\
\hline GGU 92061 & $\begin{array}{l}\text { Pegmatite from dunite with } \\
\text { chromite banding }\end{array}$ & East of Tasiussarssuaq, Fiskefjord & $65^{\circ} 00^{\prime} \mathrm{N}, 51^{\circ} 34^{\prime} \mathrm{W}$ & $\mathrm{Bi}$ & 8.9 & 0.3455 & $2675 \pm 80$ \\
\hline 01909/LK/60 & $\begin{array}{l}\text { Garnet-biotite-anthophyllite } \\
\text { schist }\end{array}$ & Ivisârtoq, head of Godthåbsfjord & $64^{\circ} 44^{\prime} \mathrm{N}, 49^{\circ} 57^{\prime} \mathrm{W}$ & $\mathrm{Bi}$. & 8.19 & 0.3058 & $2500 \pm 20$ \\
\hline GGU 79660 & Qorqut granite & $\begin{array}{l}\text { Kûgssuánguaq, SE corner of Storø, } \\
\text { Godthåbsfjord }\end{array}$ & $64^{\circ} 13^{\prime} \mathrm{N}, 51^{\circ} 14^{\prime} \mathrm{W}$ & $\mathrm{Bi}$. & 8.90 & 0.3166 & $2550 \pm 25$ \\
\hline GGU 92557 & Amphibolite & $\begin{array}{l}\text { West side Amitsuarssugssuaq } \\
\text { north of Sermilik fjord }\end{array}$ & $63^{\circ} 36^{\prime} \mathrm{N}, 51^{\circ} 11^{\prime} \mathrm{W}$ & Hbl. & 0.57 & 0.1861 & $1865 \pm 25$ \\
\hline \multirow[t]{2}{*}{ GGU 92633} & Hornblende-biotite schist & Ikátoq fjord & $62^{\circ} 42^{\prime} \mathrm{N}, 51^{\circ} 09^{\prime} \mathrm{W}$ & Hbl. & 0.48 & 0.3488 & $2690 \pm 60$ \\
\hline & & & & Bi. & 8.60 & 0.2984 & $2470 \pm 15$ \\
\hline GGU 89827 & Grey biotite-hornblende gneiss & NE corner Ikátup nunâ & $62^{\circ} 43^{\prime} \mathrm{N}, 50^{\circ} 11^{\prime} \mathrm{W}$ & $\mathrm{Bi}$. & 8.6 & 0.2770 & $2370 \pm 30$ \\
\hline
\end{tabular}

Decay constants: $\lambda_{\mathrm{e}}=5.85 \times 10^{-11} \mathrm{y}^{-1} ; \lambda_{\beta}=4.72 \times 10^{-10} \mathrm{y}^{-1} ;{ }^{40} \mathrm{~K} / \mathrm{K}=1.19 \times 10^{-4}$ 
The age results 2860 m.y. and 3117 m.y. obtained on the two samples described above (92133 and 92126) suggest that the amphibolite facies metamorphism which affected these gneisses is at least $3100 \mathrm{~m} . \mathrm{y}$. old. It is reasonable to suggest that the biotite of sample 92133 has suffered a slight argon loss during a later thermal event.

The high age of sample 92126 could hardly be caused by excess argon, because the amount of argon required to raise the age of the biotite from about $2850 \mathrm{~m}$.y. to $3120 \mathrm{~m}$.y. is approximately $1.5 \times 10^{-2} \mu \mathrm{gat} / \mathrm{g}$, which is about three times as much as the highest amount of excess argon ever recorded in minerals. Only micas from kimberlite dykes may contain excess argon of that order of magnitude and even in this case $0.6 \times 10^{-2} \mu \mathrm{gat} / \mathrm{g}$ is the largest amount ever recorded (Zartmann et al., 1967).

The potassium value for sample 92126 was obtained as the mean of 4 determinations on two independent sample solutions. The error on the $\mathrm{K}_{2} \mathrm{O}$ value is hardly more than $5 \%$, whereas it would take a $20 \%$ increase in the potassium content to reduce the $\mathrm{K} / \mathrm{Ar}$ age to $2850 \mathrm{~m}$.y.

There is some difference of opinion between geologists working in West Greenland concerning the age of the widespread granulite facies metamorphism. The measurements above seem to favour the interpretation that the high-grade metamorphism is at least $\mathbf{3 1 0 0}$ m.y. old. However, further confirmation of such a statement is still required.

$$
2750 \pm 60 \text { m.y. hornblende }
$$

GGU 89900. Hypersthene amphibolite, west side of Ankerbugt, Tovqussaq. $64^{\circ} 53^{\prime} \mathrm{N}, 52^{\circ} 12^{\prime} \mathrm{W}$.

Only three minerals are seen in this rock: Hornblende, hypersthene and plagioclase. Hornblende is poikiloblastic enclosing smaller grains of rhombic pyroxene and feldspar. No accessory minerals were observed.

$$
2675 \pm 80 \text { m.y. biotite }
$$

GGU 92061. Pegmatite from dunite with chromite banding, east of Tasiussarssuaq, Fiskefjord. $65^{\circ} 00^{\prime} \mathrm{N}, 51^{\circ} 34^{\prime} \mathrm{W}$.

The pegmatite is made up of 5-10 mm grains of slightly bluish quartz, grey plagioclase and brown mica. The sample was not examined in thin section.

The age of 2675 m.y. from the biotite of sample 92061 agrees well with the hornblende age of $2750 \mathrm{~m} . \mathrm{y}$. from sample 89900 . These age results compare with ages determined in the Godthåbsfjord region where they range down to about $2500 \mathrm{~m}$.y. These ages may be interpreted as representing a thermal, and locally perhaps also tectonic, overprint on gneisses whose original age is more than $3100 \mathrm{~m} . \mathrm{y}$.

$$
2500 \pm 20 \text { m.y. biotite }
$$

01909/LK/60. Garnet-biotite-anthophyllite schists, Ivisârtoq, head of Godthåbsfjord. $64^{\circ} 44^{\prime} \mathrm{N}, 49^{\circ} 57^{\prime} \mathrm{W}$. Coll: Kryolitselskabet Øresund, Copenhagen. 
The major primary minerals are plagioclase, quartz, biotite, anthophyllite and garnet. The three femic minerals occur in approximately equal amounts. A little chlorite has formed as an alteration product of biotite, but it is quantitatively insignificant. Accessory minerals: opaque ore, apatite and zircon.

The schist occurs as a pelitic layer in a group of volcanic supracrustals lying unconformably on a dome structure of basement gneisses. These supracrustals were expected to be of the same age as the rocks at Isua from which a $\mathrm{K} / \mathrm{Ar}$ date of 1940 m.y. was obtained on hornblende (Lambert \& Simons, 1969). Ivisârtoq is located $60 \mathrm{~km} \mathrm{SSW}$ of Isua, so it is possible that the schist at Ivisârtoq could retain an original age of $2500 \mathrm{~m}$.y., while rocks of the same age at Isua were partly up-dated as a result of local thermal or tectonic activity.

$$
2550 \pm 25 \text { m.y. biotite }
$$

GGU 79660. Qôrqut granite, Kûgssuánguaq, SE corner of Storø, Godthåbsfjord. $64^{\circ} 13^{\prime} \mathrm{N}, 51^{\circ} 14^{\prime} \mathrm{W}$.

Medium-grained granite composed of mainly quartz, K-feldspar, plagioclase and biotite. The $\mathrm{K}$-feldspar is a perthitic microcline showing intense cross-hatched twinning. Plagioclase grains are quite rich in mineral inclusions. Larger plagioclase grains are corroded and partly replaced by microcline. Biotite is green and some large grains are partly replaced by colourless mica. No chlorite is present. Small crystals of epidote are common, especially in association with biotite. Grains of apatite and opaque ore are present, but rather scarce.

This age determination disproves the earlier assumption that the Qôrqut granite is 1820 m.y. old (Larsen \& Møller, 1968). This young age was determined on biotite from a pegmatite associated with the Qorrqut intrusion. According to V. R. McGregor (personal communication) the low age determined on this pegmatite may be explained by the presence of a late fault about $1 \mathrm{~km}$ north of the sample locality.

\section{$1865 \pm 25$ m.y. hornblende}

GGU 92557. Amphibolite, west side of Amitsuarssugssuaq, north of Sermilik fjord. $63^{\circ} 36^{\prime} \mathrm{N}, 51^{\circ} 11^{\prime} \mathrm{W}$.

The amphibolite rock has formed from a $20 \mathrm{~m}$ wide E-W dolerite dyke, where it is displayed by a major N-S fault. The same fault can be followed northwards to Ameralik fjord, where it is seen to cut the Qôrqut granite.

In thin section one can see that the rock has been heavily sheared and has subsequently crystallised at fairly low-grade metamorphic conditions. The green to bluish-green hornblende, which makes up more than $60 \%$ of the rock, has crystallised to a dense mass of fine-grained euhedral crystals. The matrix between the hornblende grains consists of quartz, plagioclase, epidote and chlorite. The common grain size of the matrix is below $0.1 \mathrm{~mm}$; a few hornblende and plagioclase grains reach a size of $0.5 \mathrm{~mm}$. Stringers of crushed ore and leucoxene follow the marked foliation of the amphibolite. 
The age agrees well with the age determined earlier on biotite from pegmatites in the vicinity of the Qôrqut granite. As mentioned above this dates the last movement along major fault zones in the Ameralik-Godthåbsfjord region. This faulting apparently continues south to Sermilik fjord, where the hornblende of sample 92557 gives an age of $1865 \mathrm{~m} . \mathrm{y}$., which is probably a better estimate of the time of major faulting than is the date on pegmatite from Ameralik fjord.

$$
\begin{gathered}
2690 \pm 60 \text { m.y. hornblende } \\
2470 \pm 15 \text { m.y. biotite }
\end{gathered}
$$

GGU 92633. Hornblende-biotite schist, Ikátoq fjord. $62^{\circ} 42^{\prime} \mathrm{N}, 51^{\circ} 09^{\prime} \mathrm{W}$.

The sample was taken from a greenschist layer in the metavolcanic Ikátoq supracrustal belt. The schist is composed of quartz, plagioclase, biotite and hornblende. Hornblende is poikiloblastic enclosing many smaller grains of quartz and feldspar. A little ore is also present.

The dates recorded on this sample (2690 m.y. and 2470 m.y.) offer a better estimate of the ages of these rocks than did the previous date of $2200 \pm 160 \mathrm{~m}$.y. (Larsen \& Møller, 1968) on a hornblende schist.

$$
2370 \pm 30 \text { m.y. biotite }
$$

GGU 89827. Grey biotite-hornblende gneiss, NE corner Ikátup nunâ. $62^{\circ} 43^{\prime} \mathrm{N}, 50^{\circ} 11^{\prime} \mathrm{W}$.

The sample represents the gneiss immediately below the Ikátoq metavolcanics. The sample was taken ca. $10 \mathrm{~m}$ below the transition zone between gneiss and greenschist. The gneiss is composed of quartz, plagioclase, biotite (green/brown) and hornblende (green). The minerals display an even-grained equilibrium texture. Accessories are apatite and ore.

The ages of biotite and hornblende from samples 89827 and 92633 are in fairly good agreement. The higher hornblende age is probably a result of the better argon retention of this mineral. The age of formation of the rocks is probably over 2700 m.y.

\section{References}

Lambert, R. St. J. \& Simons, J. G. 1969: New K/Ar age determinations from southern West Greenland. Rapp. Grønlands geol. Unders. 19, 68-71.

Larsen, O. \& Møller, J. 1968: K/Ar age determinations from western Greenland 1. Reconnaissance programme. Rapp. Grønlands geol. Unders. 15, 82-86.

Zartmann, R. E., Brock, M. R., Heyl, A. V. \& Thomas, H. H. 1967: K/Ar and Rb/Sr ages of some alkalic intrusive rocks from central and eastern United States. Am. J. Sci. 265, 848-870. 